\title{
Jiřina Šiklová - Kočka, která nikdy nespí
}

\section{Linda Sokačová}

Dne 22. května zemřela Jiřina Šiklová - disidentka, socioložka, zakladatelka genderových studií v České republice i nestorka sociální práce. Její energie, nápady, komentáře i schopnost druhé nadchnout a motivovat k dalšímu aktivismu tu budou jednoznačně chybět.

Jiřina Šiklová byla už za svého života legendou, ale ne takovou, kterou známe jen ze stránek lesklých časopisů nebo televizní obrazovky. V jistém smyslu to zní jako klišé, ale Jiřina skutečně byla schopna promlouvat s lidmi v nouzi, i s intelektuály. Dokázala s nimi mluvit jazykem, jemuž rozuměli, ale uměla jim i naslouchat a snažila se porozumět. Projevilo se to i po její smrti, kdy sociální sítě nezažívaly obvyklé boje dvou nesmiřitelných táborů obdivovatelů a kritiků - ale většina, jež o Jiřině věděla a znala ji, vyjadřovala svưj smutek a truchlila. Své vzpomínky doprovázeli velmi často i společnou fotografií s Jiřinou. Jiřina Šiklová byla neustále mezi lidmi. Fyzicky se s nimi stýkala na různých akcích, ale neváhala zatelefonovat nebo napsat, když měla nějaký nápad nebo návrh, který by dotyční mohli zrealizovat nebo jinak zúročit. A bylo jí jedno, zda to je člověk na ředitelské, nebo asistentské pozici. Hodnotu pro ni měli všichni stejnou.

\section{Zakladatelka gender studies „u nás”}

$\checkmark$ roce 1991 byly v bytě Jiřiny Šiklové položeny základy genderových studií u nás vznikla knihovna genderových studií, jež je dnes součástí etablované neziskové organizace Gender Studies, o.p.s., a také byla zahájena tradice diskusí, přednášek a kolokvií k tématům spojeným s genderem, feminismem a postavením žen a mužů v evropské i americké společnosti, které byly pro české genderové a feministické hnutí klíčové a přispěly k dalšímu rozvoji v oblasti rovných príležitostí žen a mužů.

S Jiřinou jsem se bliže seznámila potom, co jsem v listopadu 2000 začala pracovat v jí založené obecně prospěšně společnost Gender Studies. Jako zakladatelka měla prominentní postavení, kterého ale nikdy nezneužívala, a organizaci, jež vznikla díky ní, umožnila rozkvět: lidem, kteří tam pracovali, věrila a nechávala jim volnou ruku. Když bylo potřeba, pomohla. Její osoba činnost Gender Studies obohacovala, umožňovala propojovat různé světy a stavět na tradici, propojovat historii se současností. I díky ní se ženské organizace, ale i Sociologický ústav AV ČR a vědecké pracoviště NKC Gender a věda zaměřly na opomíjené téma role a významu žen v českém disentu, jež bylo a bohužel stále je v české společnosti přehlíženo a zůstávalo po dlouhou dobu dostatečně nezdokumentováno. 


\section{NV ZPRÁVY / INFORMATION}

Jiřina Šiklová, obdobně jako Alena Wagnerová, byla nositelkou tématu blízkého porozumění i nepochopení mezi českým, evropským a americkým feminismem, rozdílư, které se v dobách, kdy zakládala genderová studia, projevily odlišným vnímáním světů i rolí žen a mužů v české a "západní" společnosti a spolu s tím i očekáváním, které mohou genderová studia do naší společnosti přinést. Reflexe žité reality a zkušeností Jiřina Šiklová vyjadřovala nejen v rámci genderových studií, ale i v přemýšlení o roli protestního hnutí v 60 . letech 20 . století a roli nové levice. Obě tato její svým způsobem celoživotní témata se v určitém bodě protala. Její myšlenky mohou přispět k přemýšlení o roli a postavení levice v české společnosti i dnes: "Já jsem se zabývala hnutím studentů na západě, hlavně proto, že jsme jezdili se studenty z filozofické fakulty a potkávali jsme tam studenty z těchto skupin. Pamatuju se na jaro 68, kdy bylo výročí K. Marxe. Konaly se bouřlivé manifestace studentư K oslavám Karla Marxe na západoněmeckých univerzitách. My v Čechách jsme $k$ tomu však měli takový rezervovaný vztah. Pro nás byl marxismus oficiální a i proto odmítanou filozofií. (...) O toto téma jsem se zajímala i proto, že mě zajímalo, proč se naši studenti se na tyto otázky tváří zcela opačně než na západě. Proč my nemůžeme pochopit je a proč oni nemohou pochopit nás. Po 89. roce mě na západoamerickém feminismu zajímalo to samé: proč my nerozumíme jim a oni nerozumí nám. Ženy na západě měly totiž jiné zkušenosti, obdobně to bylo v roce 68. My jsme si navzájem prĭpadali jiní, nepochopitelní a tak trochu cizí. My jsme socialismus měli v sobě $v$ reálné podobě a oni od něho čekali spásu. Domnívali se, že kdyby na Západě došlo k převratu, tak že by to mohli vést jinak."

\section{Žena tisíce témat}

Že byla Jiřina Šiklová rozkročena mezi celou řadu oborů a zájmů, dokazuje, že stála u zrodu nejen genderových studií, ale iniciovala i založení katedry sociální práce na Filozofické fakultě (kterou do roku 2000 i vedla). I proto je dodnes považována za ikonu sociální práce a v roce 2020 získala ocenění Gratias 2020 za významný prínos v sociální práci.

Její význam pro českou sociologii spočívá v tom, že otevírala nová a opomíjená témata pro českou společnost. Patří mezi ně i téma stárnutí - s tím přišla dávno před tím, než se stalo populárním tématem pro evropské fondy -, či smrti. Stárnutí se věnovala ve své úspěšné knize Deník staré paní, kterou pojala "jako praktickou pomůcku pro ty, kdo se ocitají na prahu stáří, i pro ty, kteří s nimi toto období prožívají". Generačním dialogem se zabývala ve své další knize Dopisy vnučce, kde se opět ve shodě se svým životním krédem snažila poukázat na důležitost porozumění a hledání spojitostí a podobností mezi zdánlivě odlišnými věcmi a životy vzdálených generací.

\footnotetext{
1 Nová levice v Československu. Rozhovor Lindy Sokačová s Jiřinou Šiklovou v časopise A-kontra 1/05.
} 
Důležitou hodnotou, již si ze setkávání a rozhovorů s Jiřinou odnáším, je propojování, hledání mostů a porozumění mezi zdánlivě odlišnými světy, které ale mohou být v určitém kontextu i spojenci.

\section{Osobní vzpomínka na Jiřinu Šiklovou}

\section{Lucie Vidovićová}

Je smutnou souhrou osudu, že toto číslo časopisu Gender a výzkum s podtitulem "Gender, věk a stárnutí" vychází v době, kdy odešla první dáma tématu Jiřina Šiklová (*17. 6. 1935 - † 22. 5. 2021). Její Deník staré paní jsem četla už jako doktorská studentka ve vydání nakladatelství Kalich z roku 2003. Dříve jasně růžové desky knižky jsou dnes vybledlé do jemně rưžového odstínu, který kontrastuje s křiklavě růžovou fixou označující mé poznámky v textu: „Lidé se raději přiznávají k tomu, že jsou nemocní, než k tomu, že jsou staří" (s. 53), "(d)neska nebereme život jako úděl a chceme být soběstační i ve chvílích, kdy sotva dechu popadáme" (s. 58). ${ }^{1}$

Když jsem se probírala historií e-mailů, narazila jsem na naši první korespondenční výměnu z dubna roku 2005. Prosila jsem ji o nějaké názory do projektu, který se věnoval konceptu aktivního stárnutí: "Mám vám odpovídat do e-mailu? Tak to vlepím do toho celku, to bude jako internetová diskuse? Zdravím Jiřina Šiklová," zněla její první odpověd". „Tak to pišu prímo do toho, opravdu jako asociace. Promiňte, že .... nějak je toho ted'moc, " napsala záhy omluvně, aby tím jen podtrhla, že žádný dotaz, byt' by přišel do toho nejhektičtějšího období, nezůstane nezodpovězen.

Tehdy její hlavní témata, jak podpořit koncept aktivního stárnutí, byla dvě - občanská společnost a vzdělávání: „Občanská společnost - bariérou je nedostatek podpory rozvoje občanské společnosti z hlediska státu, podnikatelů, EU..., nebot’ zde není dostatečný počet velkorysých, bohatých donátorư pro tuto oblast. Občanská společnost je $v$ ČR přehližena. Projekty a psani projektů a žádáni o granty je př́liš zprofesionalizováno, nově začínajíci "nedosáhnou” na poskytované penize. EU a její granty nutí k tzv. sitování a tato schopnost překračuje možnosti a schopnosti stárnoucích lidí tyto kontakty navazovat a takto formálně náročné projekty formulovat. Proto řada lokálních iniciativ starých lidí není realizována - nevytváří se subkultura starých lidí, nebot formálně je to pro ně náročné. Obdobně toto platí i pro svépomocné skupiny starých. Dưchodový systém - bariérou je interpretace důchodu jako "daru, výsledku

\footnotetext{
1 Šiklová, J. 2003. Deník staré paní. Praha: Kalich.
} 